\title{
Ultrasonography of the upper cervical region (EUCR) in the horse
}

\author{
Magdalena Rathmanner and Astrid B. M. Rijkenhuizen \\ University of Veterinary Medicine, Equine clinic, Vienna, Austria
}

\begin{abstract}
Summary
The examination of the equine upper cervical region is a part of the clinical examination in equine patients. Endoscopy and radiography are the most common methods to diagnose abnormalities of this region, but both methods have limitations and not all anatomic components of the upper cervical region can be evaluated. The technique of visualisation, the ultrasonographic appearance and dimensions of many anatomical structures of the equine upper cervical region have not been described yet. The purpose of the present study was to describe the normal ultrasonographic appearance of many anatomical structures of the equine upper cervical region and to present the optimal positions of the transducer and possible limitations of this examination technique. Five cadaveric specimens and fifteen healthy adult horses were used. The following anatomic structures were examined: the parotid, mandibular and thyroid gland, the parotid lymph nodes, the deep cervical cranial lymph nodes, the retropharyngeal lymph nodes, the stylohyoid angle, the paracondylar process of the occipital bone, the guttural pouch wall, the larynx and pharynx muscles, the common carotid artery and the jugular vein with its branches. Ultrasonography of the equine upper cervical region is a non-invasive method, which can support other diagnostic imaging tools. The normal parameters and images established in this study can improve the clinical understanding of diseases in this region.
\end{abstract}

Keywords: horse / ultrasound / upper cervical region / sonography / diagnostic imaging

\section{Ultrasonographische Untersuchung der oberen Halsgegend beim Pferd}

Darstellung ultrasonographisch zugänglicher Strukturen in der oberen Halsgegend und die Bestimmung ihrer Dimensionen sowie Erarbeitung eines ultrasonograpischen Untersuchungsganges sind Ziel dieser Untersuchung. Dafür wurden fünf im Bereich der Halsmitte abgesetzte Köpfe von adulten, euthanasierten Pferden ohne klinisch feststellbare Probleme in der oberen Halsgegend ultrasonographisch untersucht. Die Organe wurden unter Ultraschallkontrolle mit Tinte markiert und in der darauf folgenden Sektion wurde kontrolliert, ob die sonographisch dargestellten Strukturen den anatomischen Organen entsprechen. Danach wurden fünfzehn lebende, adulte Pferde ohne klinisch feststellbare Veränderungen in der oberen Halsgegend untersucht. Die anatomischen Ausmaße der Ohrspeicheldrüse, Unterkieferspeicheldrüse und der Schilddrüse wurden ausgemessen. Die Sondenposition, die Darstellbarkeit und das sonographische Erscheinungsbild der lokalen Lymphknoten, Trachea, Stylohyoid, der lateralen und medialen Luftsackbucht, Schlundkopf- und Kehlkopfmuskulatur sowie der Aufzweigungen der Arteria carotis communis und der Vena jugularis externa wurden beschrieben. Die Sonographie als nicht invasive, reproduzierbare und einfach durchzuführende Methode stellt eine geeignete Art der bildgebenden Diagnostik für die Untersuchung der oberen Halsgegend beim Pferd dar. Die in dieser Studie erhobenen anatomischen Parameter sowie das normale ultrasonographische Erscheinungsbild der untersuchten Strukturen können als Grundlage zur Feststellung von pathologischen Veränderungen im Bereich der oberen Halsgegend beim Pferd verwendet werden.

Schlüsselwörter: Pferd / ultrasonographische Untersuchung / obere Halsgegend / Ultraschall / bildgebende Diagnostik

\section{Introduction}

Gross palpation of the equine upper cervical region (EUCR) is part of the clinical examination in each patient. In case of clinical problems the complexity of this region makes diagnoses of abnormalities challenging. Endoscopy and radiology are useful tools in clinical diagnostics but both methods have limitations and not all anatomic components of the EUCR can be evaluated (Chalmers et al. 2006, Cehak et al. 2010, Linford et al. 1983). Computed tomography and magnet resonance imaging offer more diagnostic possibilities (Pekarkova et al. 2009, Sasaki et al. 1999). However, both methods are expensive and require specialized facilities and equipment.

Previously the ultrasonographic topography of the EUCR and the use of ultrasound for the evaluation of the anatomy of the larynx have been described (Chalmers et al. 2006, Künzel and Probst 1994). The clinician is able to evaluate a portion of the hyoid apparatus, the laryngeal cartilages, associated soft tissue and the intrinsic and extrinsic laryngeal musculatu- re. As already known ultrasonography allows to diagnose and to localize arythenoid chondritis, abcessation, perilaryngeal inflammation and laryngeal dysplasia (Chalmers et al. 2006, Garrett et al. 2009). Unfortunately, the technique of visualisation, the normal ultrasonographic appearance and dimensions of other anatomical structures of the EUCR have not been described.

Ultrasonographic imaging has great potential for the assessment of the anatomy and diseases of the equine head. The purpose of the present study was to describe the normal percutaneous ultrasonographic appearance of anatomic structures within the EUCR of a healthy horse and to measure normal dimensions of the parotid, mandibular and thyroid gland as well as to relate these findings to the corresponding gross anatomy. This study tests the hypothesis that ultrasonography gives an accurate representation of the structures of the EUCR. 


\section{Materials and Methods}

\section{Post mortem study}

The EUCR of the cadavers of five mature horses were examined (mean age 14.8 years, range 13-20 years, mean body weight $556 \mathrm{~kg}$, four mares, one gelding, two Draft horses, one Warmblood, one Thoroughbred and one Arabian). All these horses were euthanized for a reason other than problems of the EUCR and the cadavers were stored at $4^{\circ} \mathrm{C}$ of maximum 5 days until examination.

The head with neck was separated from the body between the third and fourth cervical vertebra. Each cadaver was examined in right and left lateral recumbency. The hair of the EUCR (horizontal: between mandibular ramus and the atlas wing and vertical: between the ear base and the midline of the larynx) was clipped and the skin was prepared with $70 \%$ isopropyl alcohol and ultrasound gel as an acoustic coupling agent.

Ultrasonography of the EUCR was performed with an ultrasound machine* using a $7 \mathrm{MHz}$ linear transducer. The optimal transducer position with repeat accuracy for imaging structures was defined as well as the points for measurements of the parotid dimensions as well as the mandibular and thyroid gland. To ensure the anatomical localisation of the underlying structures, each structure identified with ultrasound was injected with dye* under ultrasonographic guidance. Immediately after ultrasonographic examination, gross dissection of the cadaveric specimens was performed. The ultrasonographic findings were verified by visualization of dye deposited in the injected structures.

The following anatomic structures of the EUCR were examined for their location and ultrasonographic appearance: the parotid gland, mandibular gland, thyroid gland, parotid lymph nodes, deep cervical cranial lymph nodes, lateral and medial retropharyngeal lymph nodes, stylohyoid angle, paracondylar process of the occipital bone, wall of the lateral and medial compartment of the guttural pouch, parotidoauricular muscle, occipitomandibular muscle, occipitohyoid muscle, stylohyoid muscle, cricopharyngeus muscle, thyropharyngeus muscle, hyopharyngeal muscle, thyrohyoid muscle, sternothyroid muscle, cricothyroid muscle, dorsal cricoarytenoid muscle and the common carotid artery (a.) and jugular vein (v.) and its branches. Findings were recorded (protocol) and photographs obtained.

\section{In vivo study}

On base of experience from the post mortem study, 15 adult horses (including six mares, nine geldings, ten Warmbloods, five Standardbreds, one Thoroughbred) without known problems of EUCR were examined. Age of these horses ranged between $8-27$ years (mean age 15 years) and the mean body weight was $523 \mathrm{~kg}$. All animals were examined without sedation, restricted in stocks with the head held in natural position. The examined area was prepared in the same way as in the post mortem study. The percutaneous ultrasonographic examination of all forementioned anatomic structures was performed in each horse on the left and right side in a standardized fashion. All structures were evaluated for echogenicity, location and ultrasonographic appearance. The dimensions of the parotid gland, mandible gland, and thyroid gland were measured using the electronic caliper (accuracy of measurement: $0,1 \mathrm{~mm}$ ) incorporated in the ultrasound machine. The thickness, width or length was measured as a perpendicular line drawn between the borders of the viscera. All examinations were performed by one veterinarian (M.R.) and each measurement was repeated 3 times to ensure accuracy. To facilitate measurement of the structures, measurement points were defined.

\section{Measurement of the parotid gland}

The thickness (on the sonogram: from dorsal to ventral) of the parotid gland was measured at three points. 1A: at the level of the temporo-mandible joint with the transducer kept sagittal to the parotid gland, parallel to the caudal border of the mandibular ramus (Fig. 1A); 1B: at the level of the stylohyoid angle with the transducer kept sagittal to the parotid gland, parallel to the caudal border of the mandibular ramus (Fig. 1B); 1C: at the level of the mandibular angle with the transducer kept sagittal to the parotid gland (Fig. 1C). The measurement of the parotid gland for $1 \mathrm{C}$ was performed when the parotid gland, the mandibular gland and the common carotid a. (the longitudinal view) were visible all-together on one sonogram (Fig. 5).

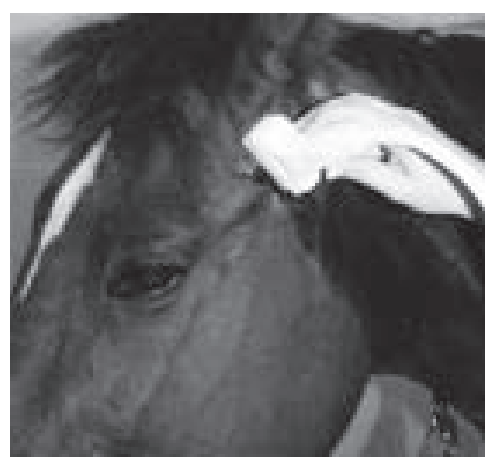

Fig. 1A Measuring point for the parotid gland 1A: at the level of the temporo-mandibular joint with the transducer kept sagittal to the parotid gland, parallel to the caudal border of the mandibular ramus.

Messpunkt für die Gl. parotidea 1A: Höhe des Temporomandibulargelenkes mit sagittaler Schallkopfhaltung im Verhältnis zur Gl. parotidea, parallel zum Kaudalrand des Ramus mandibulae.

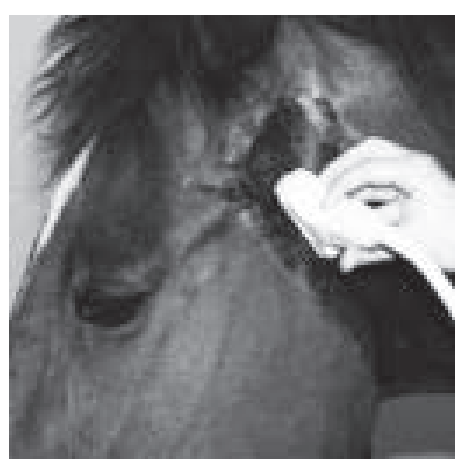

Fig. 1B Measuring point for the parotid gland 1B: at the level of the stylohyoid angle with the transducer kept sagittal to the parotid gland, parallel to the caudal border of the mandibular ramus.

Messpunkt für die Gl. parotidea IB: Höhe des Stylohyoid-Winkels mit sagittaler Schallkopfhaltung im Verhältnis zur Gl. parotidea, parallel zum Kaudalrand des Ramus mandibulae. 
Measurement of the mandibular gland

The width (on the sonogram: from the left to the right) and thickness (on the sonogram: from dorsal to ventral) of the mandibular gland were measured at the above described measuring point $1 \mathrm{C}$.

\section{Measurement of the thyroid gland}

The length (on the sonogram: from the left to the right) and thickness (on the sonogram: from dorsal to ventral) of the thyroid gland were measured with the transducer kept parallel to the trachea (Fig. 2). All measurements described above were performed with a transducer penetration depth of $6 \mathrm{~cm}$. Further-more all other characteristic structures of the EUCR recognized during the post mortem study were tried to visualise in the live horses. The optimal transducer position and penetration depth for each imaging structure were defined.

\section{Statistical analysis}

The mean and standard deviation of the parameters of measured structures were calculated. Analysis of variance between groups of different gender or age was performed. Com-

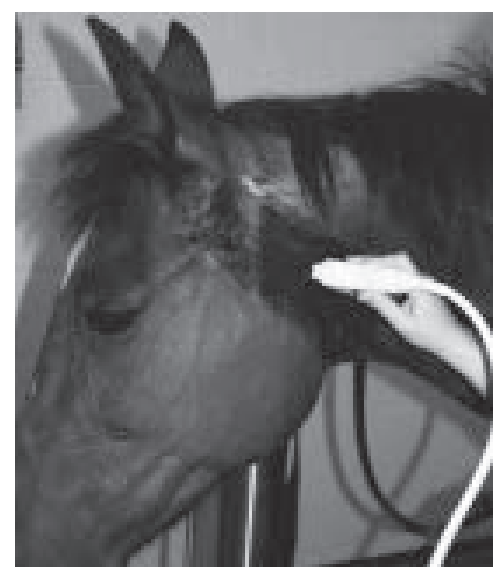

Fig. 1C Measuring point for the parotid gland 1C: at the level of the mandibular angle with the transducer kept sagittal to the parotid gland.

Messpunkt für die Gl. parotidea 1C: Höhe des Kieferwinkels mit sagittaler Schallkopfhaltung im Verhältnis zur Gl. parotidea.

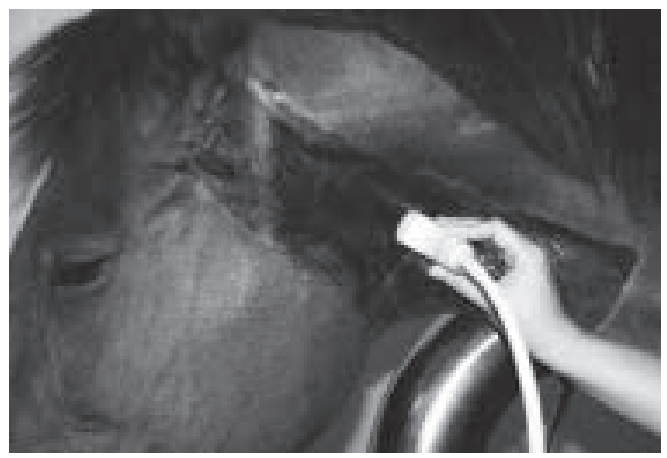

Fig. 2 The transducer is positioned parallel to the trachea for measurement of the thyroid gland.

Für die Messung der Schilddrüse wird der Schallkopf parallel zur Trachea gehalten. parisons between the right and left side were performed using the paired t-test.

\section{Results}

Post mortem study

The appearance and dimension of all correctly identified anatomic structures confirmed by accurate location of the colored dye in the post mortem study are presented in the results of the in vivo study. The parotid-and lateral retropharyngeal lymph nodes, the stylohyoid-and thyreohyoid muscles and the thyropharyngeus and hyopharyngeal muscles could not be identified in the post mortem study. The differentiation between the parotid gland and the parotid lymph nodes in the gross dissection was difficult because of the similar glandular texture of these two structures and its anatomical neighbourhood. Ultrasonographically the parotid gland appeared homogeneous and of increased echogenicity relative to the adjacent muscle. The appearance was very similar to that of

Table 1 Summary of the ultrasonographic presentability of examined structures in live horses. In brackets the number of detected structures if different as 30. / Zusammenfassung der Darstellbarkeit der untersuchten Strukturen bei lebenden Pferden. Bei einer Darstellbarkeit die von 30 abweicht, werden entsprechende Werte in Klammern angeführt.

\begin{tabular}{lc}
\hline \multicolumn{1}{c}{ Structure } & $\begin{array}{c}\text { Ultrasonographic } \\
\text { presentability }\end{array}$ \\
\hline Parotid gland & + \\
Mandibular gland & + \\
Thyroid gland & + \\
Parotid lymph nodes & - \\
Deep cervical cranial lymph nodes & + \\
Lateral retropharyngeal lymph nodes & - \\
Medial retropharyngeal lymph nodes & $(4 / 30)$ \\
Stylohyoid angel & + \\
Paracondylar process of the occipital bone & + \\
Wall of the lateral compartment of the guttural & + \\
Wall of the medial compartment of the & + \\
Parotidoauricular muscle & + \\
Occipitomandibular muscle & + \\
Occipitohyoid muscle & + \\
Stylohyoid muscle & + \\
Cricopharyngeus muscle & + \\
Thyropharyngeus muscle & + \\
Hyopharyngeal muscle & + \\
Thyrohyoid muscle & + \\
Sternothyroid muscle & + \\
Doricothyroid muscle & + \\
Common cricoarytenoid muscle & + \\
Ramifications of common carotid artery & + \\
\hline & + \\
\hline & + \\
\hline & + \\
\hline
\end{tabular}


the adjacent lymph nodes, making these two structures almost undistinguishable on ultrasound.

The lateral retropharyngeal lymph nodes were also not detectable because of their small size in the healthy, adult horses. The stylohyoid muscle could not be visualized in any cadaver. This muscle is located medial to the stylohyoid bone and in direct neighbourhood to the occipitomandibular muscle. This muscle had a similar echo texture to the occipitomandibular muscle and was additionally overshadowed by the stylohyoid bone. The thyropharyngeus, the hyopharyngeal and the thyrohyoid muscles could not be visualised as well, since the ultrasonographic approach in this region was limited by the mandibular ramus, which caused a lack of an appropriate acoustic window.

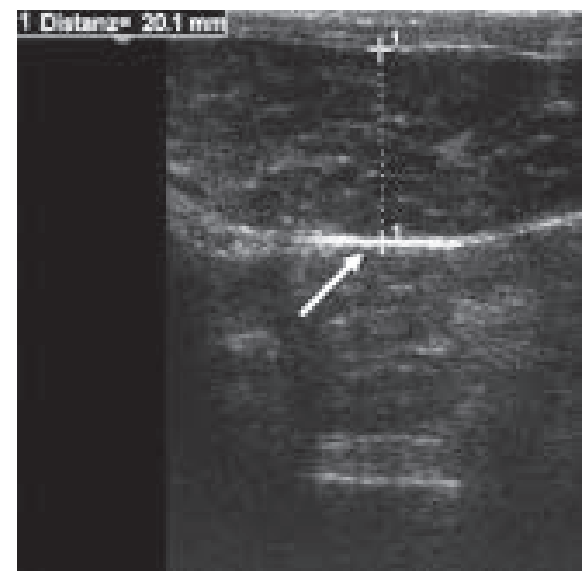

Fig. 3 An ultrasonographic longitudinal view of the parotid gland at the measuring point $1 \mathrm{~A}$. On the sonogram proximal is to the left. The line drawn from 1 to 1 represents the thickness of the parotid gland. The wall of the lateral compartment of the guttural pouch is marked with an arrow.

Longitudinale Abbildung der Gl. parotidea am Messpunkt 1A. Auf dem Ultraschallbild entspricht links - proximal. Die Linie, die die Punkte 1 und 1 verbindet, entspricht der Dicke der Gl. parotidea. Der weiße Pfeil markiert die Wand der lateralen Abteilung des Luftsackes.

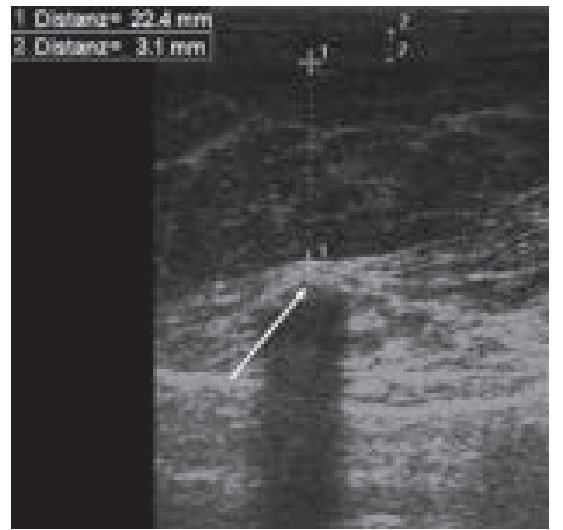

Fig. 4 An ultrasonographic longitudinal view of the parotid gland at the measuring point 1B. On the sonogram proximal is to the left. The line drawn from 1 to 1 represents the thickness of the parotid gland. The line drawn from 2 to 2 represents the thickness of the parotidoauricular muscle. The stylohyoid angle is marked with an arrow. Longitudinale Abbildung der Gl. parotidea am Messpunkt 1 B. Auf dem Ultraschallbild entspricht links - proximal. Die Linie, die die Punkte 1 und 1 miteinander verbindet, stellt die Dicke der Gl. parotidea dar. Die Linie von Punkt 2 zu Punkt 2 stellt den Durchmesser des M. parotidoauricularis dar. Der Stylohyoid - Winkel wird durch einen Pfeil gekennzeichnet.
In vivo study

There was no significant difference in size of the described organs between the left and right side of the horse and no significant gender and age correlations. The detection ability of the examined horses is presented in the table 1.

The parotid gland, localised very superficially between the caudal mandibular border, the atlas wing, the base of the ear and ventrally bordered by the linguofacial v. was visualised in all 15 adult horses. The normal parotid gland has a homogeneous echo texture with a glandular pattern and a characteristic fibrous capsule clearly delimitable from the

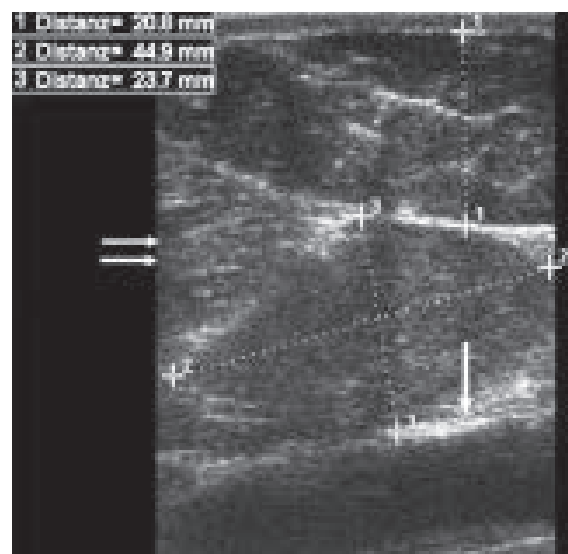

Fig. 5 An ultrasonographic longitudinal view of the parotid gland and the transversal view of the mandibular gland at the measuring point 1C. On the sonogram proximal is to the left. The line drawn from 1 to 1 represents the thickness of the parotid gland. The line drawn from 2 to 2 represents the width of the mandibular gland, the line from 3 to 3 represents the thickness of the mandibular gland. The common carotid artery is marked with an arrow and the part of the occipitomandibular muscle is labelled with two arrows. Longitudinale Ansicht der Gl. parotidea und Transversalschnitt der Gl. mandibularis am Messpunkt 1C. Auf dem Ultraschallbild entspricht links - proximal. Die Verbindungslinie zwischen 1 und 1 markiert die Dicke der Gl. parotidea, die zwischen 2 und 2 die Breite der Gl. mandibularis und die zwischen 3 und 3 die Dicke der Gl. mandibularis. Der weiße Pfeil zeigt auf die A. carotis communis. Ein Teil des M. occipitomandibularis ist durch die beiden weißen Pfeile gekennzeichnet.

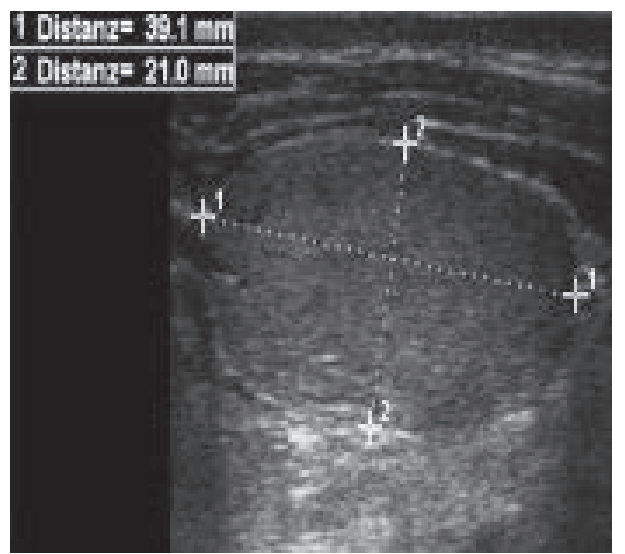

Fig. 6 An ultrasonographic longitudinal view of the thyroid gland. On the sonogram cranial is to the left. The line drawn from 1 to 1 represents the length and the line from 2 to 2 the thickness of the thyroid gland.

Longitudinale Ansicht der Schilddrüse. Auf dem Ultraschallbild entspricht links - kranial. Die Verbindungslinie von 1 zu 1 markiert die Länge, die von 2 zu 2 die Dicke der Schilddrüse. 
surrounding tissues. The mean measured thickness of the parotid gland in 1A was $21.2( \pm 2.9) \mathrm{mm}$. At this point the wall of the lateral compartment of the guttural pouch was seen as a hyperechogenic line lying directly underneath the parotid gland (Fig. 3). At the measuring point 1B the mean thickness of the parotid gland was $17.3( \pm 3.8) \mathrm{mm}$. At this point the stylohyoid angle was recognised as a hyperechogenic structure causing a typical bone shadow and the bandlike parotidoauricular muscle with its longitudinal fibres was seen immediately under the skin (Fig. 4). The mean thickness of the parotid gland at the measuring point $1 \mathrm{C}$, situated at the level of mandibular angle, was $17.1( \pm 2.8) \mathrm{mm}$. At this point the mandibular gland could be recognised medial to

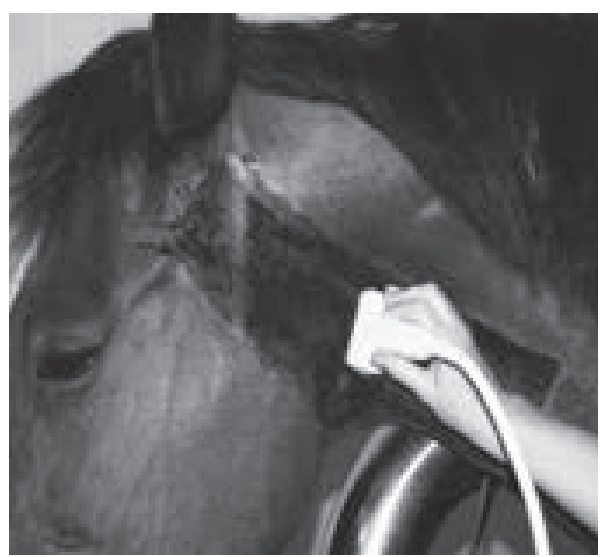

Fig. 7A The transducer position for imaging of the deep cervical cranial lymph nodes: the transducer is positioned transversal to the proximal part of the jugular groove and moved along the jugular vein from caudal to rostral.

Die Schallkopfposition zur Darstellung der Lnn. cervicales craniales: der Schallkopf wird transversal im proximalen Bereich des Sulcus jugularis gehalten und entlang der V. jugularis externa von kaudal nach rostral geführt.

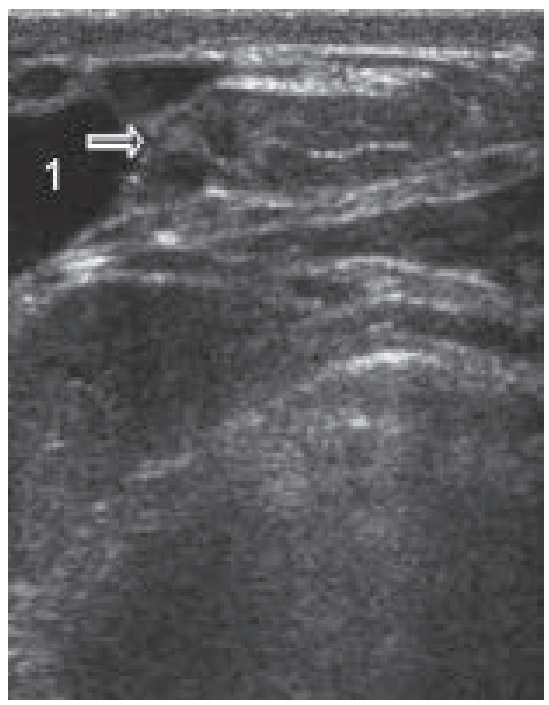

Fig. 7B An ultrasonographic view of the deep cervical cranial lymph nodes (arrow): small, oval, hypoechogenic structures; immediately rostral to the ramification of the external jugular vein (1). On the sonogram dorsal is to the left. The external jugular vein was manually raised during the exposure for better orientation.

Ultraschalldarstellung der Lnn. cervicales craniales (Pfeil): Kleine, ovale, hypoechogene Strukturen; unmittelbar rostral der Aufzweigung der V. jugularis externa (1). Auf dem Ultraschallbild entspricht links dorsal. Die V. jugularis externa wurde während des Schallvorganges zur besseren Orientierung manuell gestaut. the parotid gland. This smaller salivary gland is located between the parotid gland, the tendon of insertion of the sternomandibular muscle, the digastric muscle and the maxillary vein. The ultrasonographic view of the mandibular gland showed slightly more echogenicity than the parotid gland, had a homogeneous structure and the capsule could almost not be differentiated. The mean width of the mandibular gland was $38.6( \pm 5.3) \mathrm{mm}$ and the mean thick-ness 14.1 $( \pm 3.2) \mathrm{mm}$. In this projection the common carotid artery was recognised (in its longitudinal view) immediately medial to the mandibular gland and the occipitomandibular part of the digastric muscle, right in between the parotid and mandibular gland (Fig. 5).

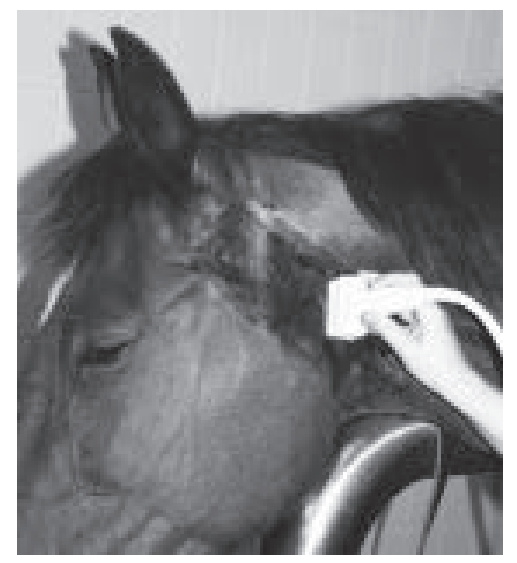

Fig. 8A The transducer position for imaging the medial retropharyngeal lymph nodes. The transducer positioned approximately $4 \mathrm{~cm}$ proximal to the mandibular angle and kept in $45^{\circ}$ angle to the caudal border of the mandibular ramus.

Die Schallkopfposition zur Darstellung der Lnn. retropharyngei mediales. Der Schallkopf wird etwa $4 \mathrm{~cm}$ proximal des Unterkieferwinkels platziert in einem Winkel von $45^{\circ}$ zum Kaudalrand des Ramus mandibulae.

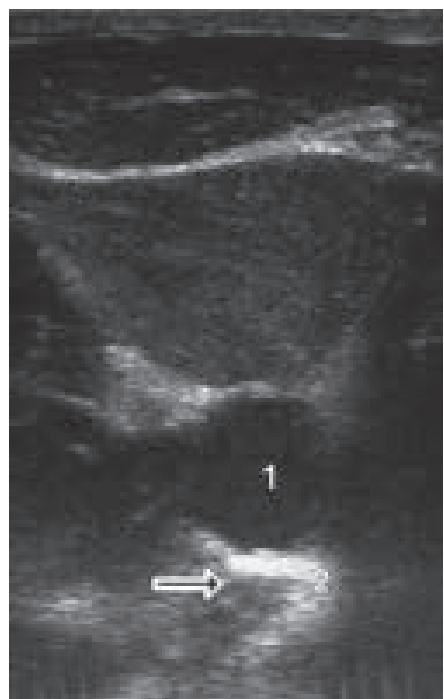

Fig. 8B An ultrasonographic view of the medial retropharyngeal lymph nodes (arrow): small and round structures in the direct neighbourhood of the common carotid artery (1) and the hyperechogenic wall of the medial compartment of the guttural pouch (2). On the sonogram dorsal is to the left.

Ultrasonographische Darstellung der medialen retropharyngealen Lymphknoten (Pfeil): kleine, rundliche Strukturen in direkter Nachbarschaft zur A. carotis communis (1) und die hyperechogene Wand der medialen Luftsackabteilung (2). Auf dem Ultraschallbild entspricht links - dorsal. 
The thyroid gland, visualised parallel to the proximal third of the trachea, appeared as an elliptical structure with a homogeneous texture and echogenicity and a clearly visible capsule (Fig. 6). The mean length and thickness of the thyroid gland were $39.4( \pm 3.2) \mathrm{mm}$ respectively $21.6( \pm 3.3) \mathrm{mm}$.

The deep cervical cranial lymph nodes were found in all horses. They appeared as small, oval, hypoechogenic structures (Fig. 7B) located immediately rostral to the ramification of the external jugular vein. For this image the transducer was kept transversally to the proximal part of the jugular groove and was moved along the jugular vein from caudal to rostral (Fig. 7A). The transducer penetration depth

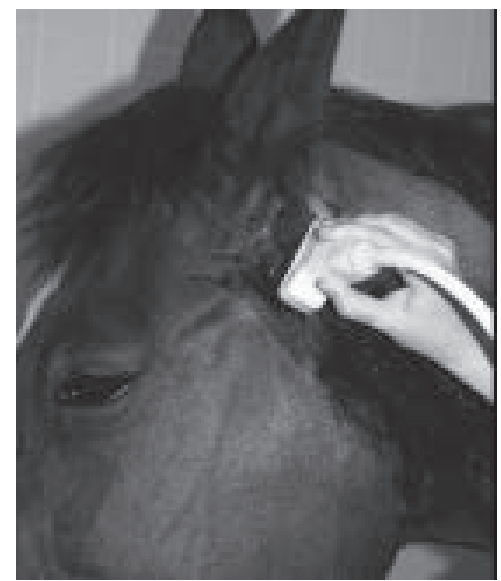

Fig. 9A The transducer position for imaging of the occipitohyoid muscle, the paracondylar process of the occipital bone and the stylohyoid angle. The transducer located approximately $4 \mathrm{~cm}$ ventrally to the base of the ear and kept perpendicular to the caudal border of the mandibular ramus.

Die Schallkopfposition zur Darstellung des M. occipitohyoideus, des Proc. paracondylaris und des Stylohyoid-Winkels. Der Schallkopf wird etwa $4 \mathrm{~cm}$ ventral des Ohrgrundes platziert in einem Winkel von 90 o zum Kaudalrand des Ramus mandibulae.

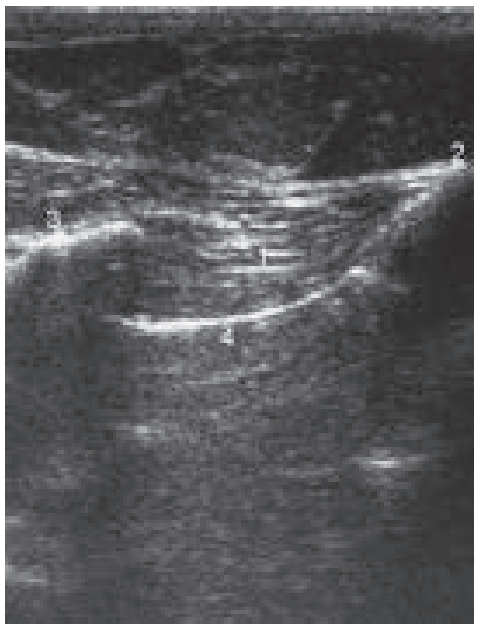

Fig. 9B An ultrasonographic view of the occipitohyoid muscle (1) located between the paracondylar process (2) of the occipital bone and the stylohyoid angle (3): the hyperechogenic line directly beneath the muscle represents the wall of the medial compartment of the guttural pouch (4). On the sonogram rostral is to the left.

Ultrasonographische Darstellung des M. occipitohyoideus (1) zwischen dem Proc. paracondylaris (2) und dem Stylohyoid-Winkel (3): Die hyperechogene Linie unmittelbar unterhalb des Muskels repräsentiert die Wand der medialen Luftsackabteilung (4). Auf dem Ultraschallbild entspricht links - rostral. was $6 \mathrm{~cm}$. During examination of the latter, the external jugular vein was manually raised in the mid portion of the neck for better orientation.

The medial retropharyngeal lymph nodes were detected in one horse on the left and in 3 horses on the right side. They appeared as very small and round structures in the direct neighbourhood of the common carotid artery and the clear hyperechogenic wall of the medial compartment of the guttural pouch (Fig. 8B). The transducer penetration depth ranged between 6 and $9 \mathrm{~cm}$. The transducer was moved slightly proximal to the mandibular angle and kept in $45^{\circ}$ angle to the caudal border of the mandibular ramus (Fig. 8A).

Further movement of the transducer in the dorso-proximal direction allowed the visualisation of the ramification of the common carotid artery.

The occipitohyoid muscle is located between the paracondylar process of the occipital bone and the stylohyoid angle and was found in all horses. On the sonogram two characteristic

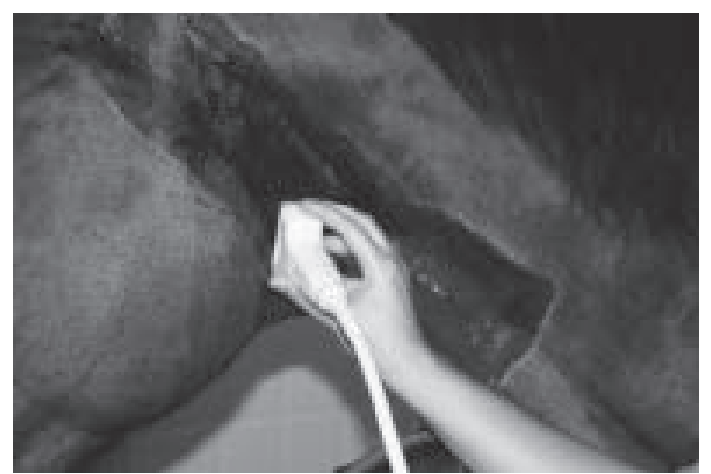

Fig. 10A The transducer position for imaging of the cricopharyngeal muscle and the dorsal cricoarytenoid muscle. The transducer is kept at the level of the circoid cartilage, longitudinally to the caudal border of the mandibular ramus.

Schallkopfposition zur Darstellung des M. cricopharyngeus und des M. cricoarytenoideus dorsalis. Der Schallkopf wird auf Höhe des Ringknorpels platziert, longitudinal zum Kaudalrand des Ramus mandibulae.

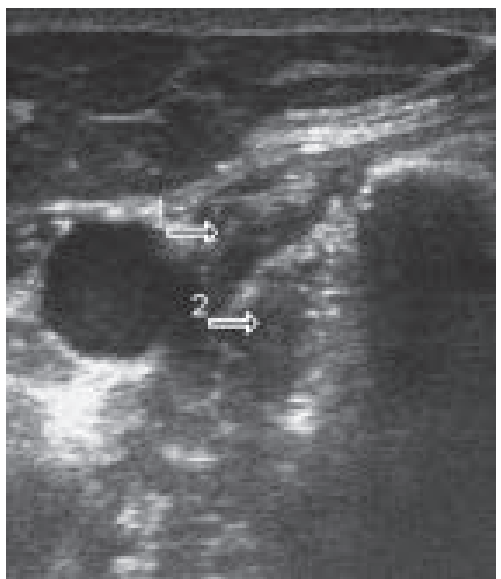

Fig. 10B A longitudinal ultrasonographic view of the cricopharyngeus muscle (arrow 1) and immediately medially to the cricopharyngeus muscle the transversal view of the dorsal cricoarytenoid muscle (arrow 2). On the sonogram dorsal is to the left. Longitudinale Ultraschalldarstellung des M. cricopharyngeus (Pfeil 1). Unmittelbar medial dazu befindet sich der M. cricoarytenoidus dorsalis (Pfeil 2). Auf dem Ultraschallbild entspricht links - dorsal. 
hyperechogenic bone shadows could be seen, the longitudinal fibers of the occipitohyoid muscle and the hyperechogenic line directly beneath the muscle that represented the wall of the medial compartment of the guttural pouch (Fig. 9B). The transducer was located approximately $4 \mathrm{~cm}$ ventrally to the base of the ear and kept perpendicular to the caudal border of the mandibular ramus (Fig. 9A).

The cricopharyngeus muscle was found in all horses. The dorsal cricoarytenoid muscle located directly beneath the cricopharyngeus muscle, was visualised in all horses (15/15) on the right and in 13 of 15 horses on the left side as well. With the transducer penetration depth of $6 \mathrm{~cm}$, the cricopharyngeus muscle was visualised in its longitudinal view. The transducer for this image was positioned at the level of the circoid cartilage, longitudinally to the caudal border of the mandibular ramus (Fig. 10A). Immediatelly medial to the cricopharyngeus muscle the transversal view of the dorsal cricoarytenoid muscle was recognised (Fig. 10B).

When the transducer, kept in the position presented on Fig. 10A, was slightly moved ventro-caudally the visualisation of the cricothyroid muscle was achieved in all horses, covered by the cricopharyngeus muscle (longitudinal view) and situated between the cricoid and thyroid cartilage (Fig. 11).

The sternothyroid muscle attaches to the ventro-lateral side of the thyroid cartilage of the larynx and continues caudally alongside the trachea. The transversal view of the muscle was identified in all horses. The muscle could be recognised as a homogen, hypoechogen oval structure next to the tracheal ring (Fig. 12B) with the transducer position presented on Fig. 12A and the transducer penetration depth of $6 \mathrm{~cm}$.

\section{Discussion}

This study provides detailed baseline information of the normal ultrasonographic anatomy of the EUCR of adult horses.

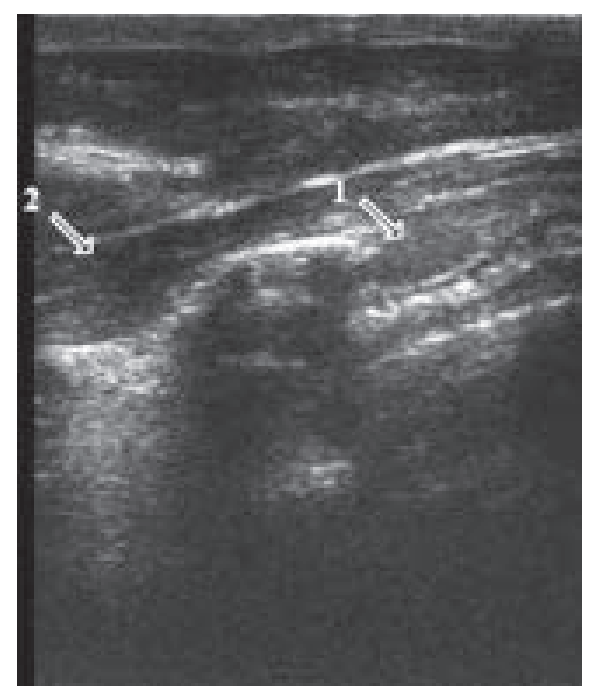

Fig. 11 An ultrasonographic view of the cricothyroid muscle (arrow 1) covered by the cricopharyngeus muscle (longitudinal view) (arrow 2). On the sonogram rostral is to the left.

Ultrasonographische Darstellung des M. cricothyroideus (Pfeil 1) in unmittelbarer Nachbarschaft zum M. cricopharyngeus (Längsschnitt) (Pfeil 2). Auf dem Ultraschallbild entspricht links - dorsal.
There was good subjective correspondence between the findings on ultrasonography and gross anatomy. No macroscopic pathological abnormalities or anatomical deviations were found in the examined horses and cadavers.

The ultrasonographic examination was performed with a 7 $\mathrm{MHz}$ linear array transducer, which is used in many equine practices. The higher-frequency transducer, used in our study, generates a shorter wavelength of ultrasound and thereby creates an image with better resolution compared to lowerfrequency transducers (Reef 1998). The linear array transducer can be electronically focused and the depth of the focal zone can be varied, improving the image quality at a precise location (Reef 1998). The examined structures of the EUCR could be clearly visualised and measured with the transducer thanks to their superficial location. The $7 \mathrm{MHz}$ linear array transducer fulfils the requirements needed for ultrasonographic examination of the EUCR.

From a clinical perspective, not all structures frequently associated with pathology localised in the EUCR, could be assessed, like the lateral and medial retropharyngeal lymph nodes or the dorsal cricoarytenoid muscle. In our study the medial retropharyngeal lymph nodes were found in only 4 of 15 the horses and the lateral retropharyngeal lymph nodes were not detected in any case. However, a previous study describes the detection of abscesses in retropharyngeal lymph nodes by

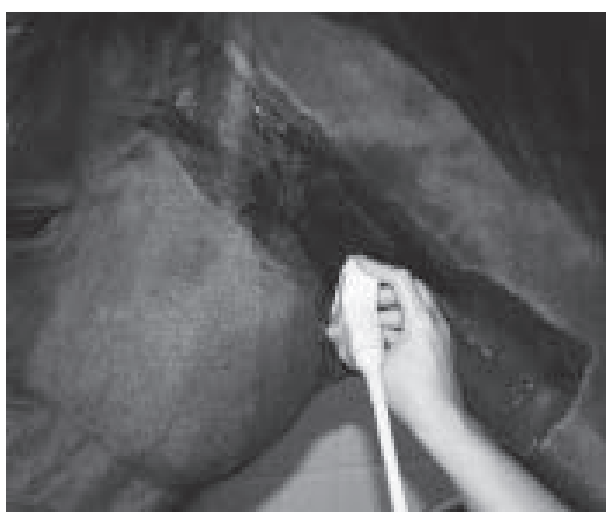

Fig. 12A The transducer position for imaging of the sternothyroid muscle.

Schallkopfposition zur Darstellung des M. sternothyroideus.

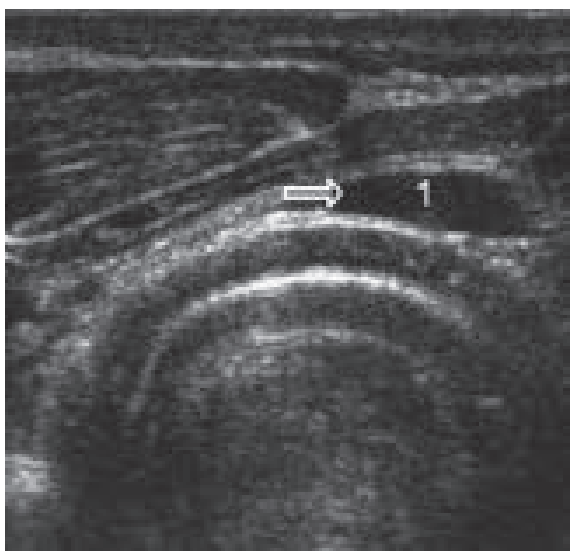

Fig. 12B An ultrasonographic view of the sternothyroid muscle (arrow) and tracheal ring (1). On the sonogram rostral is to the left. Ultrasonographische Darstellung des M. sternothyroideus (Pfeil) und eines Trachealringes (1). Auf dem Ultraschallbild entspricht links dorsal. 
ultrasonographic examination in seven horses (De Clerca et al. 2003). It can be concluded that the retropharyngeal lymph nodes can be only detected when pathological processes causing an enlargement of the lymph nodes, e.g. viral infection or abscesses, are present.

In our study the dorsal cricoarytenoid muscle was identified in 13 of 15 live horses on the left and in all 15 on the right side. The presentability and the quality of the obtained view were limited by the anatomical location of the muscle, the far rostral position of the larynx between the mandibular rami and the large shape of the transducer used in our study. A smaller transducer may allow better visualisation of this muscle and measurement of its normal dimensions.

Transcutaneous ultrasonography provides a non-invasive method for the examination of the EUCR in adult horses and can be performed relatively easy with standard ultrasound equipment in non-sedated horses. The knowledge of the ultrasonographic anatomy of the EUCR is necessary to correctly identify the structures. Ultrasound offers the ability to evaluate areas impossible to image by endoscopy or radiology. This study adds to the knowledge of the normal variation in the ultrasonographic anatomical presentation of the EUCR, and complements previous works (Chalmers et al. 2006, Künzel and Probst 1994).

The ultrasonography of the EUCR supports other diagnostic imaging tools and can improve the clinical examination of this region. Knowing the normal ultrasonographic appearance of described structures may improve the clinical understanding of the EUCR diseases.

\section{References}

Cehak A., Rohn K., Barton A. K., Stadler P. and Ohnesorge B. (2010) Effect of head and neck position on pharyngeal diameter in horses. Vet. Radiol. Ultrasound 51, 491-497
Chalmers H. J., Cheetham J., Yeager A. E. and Ducharme N. G. (2006) Ultrasonography of the equine larynx. Vet. Radiol. Ultrasound 47, 476-481

De Clercq D., Van Loon G., Nollet H., Delesalle C., Lefere L. and Deprez P. (2003) Percutaneous puncture technique for treating persisten rethropharyngeal lymph node infections in seven horses. Vet. Rec. 8, 169-172

Garrett K. S., Woodie J. B., Embertson R. M. and Pease A. P. (2009) Diagnosis of laryngeal dysplasia in five horses using magnetic resonance imaging and ultrasonography. Equine vet. J. 41: 766-771.

Künzel W. and Probst A. (1994) Ergebnisse ultraschallanatomischer Untersuchungen der oberen Halsgegend des Pferdes. Pferdeheilkunde 10, 243-251

Linford R. L., O'Brien T. R., Wheat J. D. and Meagher D. M. (1983) Radiographic assessment of epiglottic length and pharyngeal and laryngeal diameters in the Thoroughbred. Am. J. Vet. Res. 44, 1660-1666

Pekarkova M., Kircher P. R., Konar M., Lang J. and Tessier C. (2009) Magnetic resonance imaging anatomy of the normal equine larynx and pharynx. Vet. Radiol. Ultrasound 50, 392-397

Reef V. B. (1998) Physics and instrumentation. In: Equine diagnostic ultrasound. Philadelphia: W.B. Saunders Company, 1-23

Sasaki M., Hayashi Y., Koie H., Yamaha Y., Kimura J., Mangali D., Kawashima S., Endo H. and Yamamtoto M. (1999) CT examination of the guttural pouch (auditory tube diverticulum) in Przewalski's Horse (Equus przewalskii). J. Vet. Med. Sci. 61, 1019-1022

Magdalena Rathmanner

Stiffung Tierärztliche Hochschule Hannover

Klinik für Pferde

Bünteweg 9

30559 Hannover

mrathmanner@gmx.net 